are so often ignored by academic historians in Brazil. In the future it should prove to be an important source on the urban Brazil of the 1980s, but for the present historians who study urbanization or popular culture will find it of interest.

Pictorial images of slaves are included in the excellent Escravos Brasileiros do seculo XIX na fotografia de Christiano Jr., ed. by Paulo Cesar de Azevedo and Mauricio Lissovsky with notes by Jacob Gorender, Manuela Carneiro da Cunha, and Muniz Sodré (São Paulo: Editora Ex Libris Ltda, 1988. Pp. 36.77 photographs). Not only are the photographs sharp, detailed portraits of Africans in Rio, but they also reproduce dress styles (both African and Luso-Brazilian), and items of material culture (baskets, drums, and hats), methods of head porterage, and a congada (with king, queen, and drummers). This is an essential addition to any library with a collection on Brazilian slavery.

Finally, the Biblioteca Nacional has published a catalogue of its documentary and pictorial exposition on Brazilian slavery: Para Uma História do Negro no Brasil (Rio de Janeiro: Biblioteca Nacional, 1988. Pp. 64. Illustrations. Photograph). It includes a list of 140 items in the exposition with the reproduction of some of them. Of particular interest is the illustration of the plan of the Quilombo of São Gonçalo in the district of Paracatu, Minas Gerais. Since few plans of Brazilian quilombos have so far been located, this is a unique pictorial record of a small quilombo of Minas Gerais.

M.K.

\title{
OBITUARY
}

\section{HaRold EugENE Davis, 1902-1988}

Harold Eugene Davis died at his home in Chevy Chase, Maryland, on September 13,1988 , at the age of 85 . He had been in declining health for several months. Dr. Davis had been on the faculty of The American University from 1947 until his retirement in 1973 with the rank of university professor emeritus. Trained as a historian, Dr. Davis was a leader in the movement asserting a common history of the Americas, and noted for his writings on Latin American social and political thought. He was also a pioneer in the modern study of Latin American international and comparative politics.

Harold Davis, of Welsh heritage, was born December 3, 1902, in Girard, Ohio, and grew up in Niles, Ohio. He graduated from Hiram College, and earned a master's degree from the University of Chicago and a Ph.D. from Western (now Case-Western) Reserve University. In 1929, Harold married Audrey Hennen, a member of the music faculty at Hiram College, who continues to reside in Chevy Chase. Harold is also survived by their daughter, Barbara Lee Owen, and by three grandchildren, two great grandchildren, a brother, and a sister.

From 1927 until 1947, he was a member of the faculty of Hiram College, where 
he served as a department chair and as a dean. During World War II, he took leave to work in Washington, D.C., in Nelson Rockefeller's Office of the Coordinator of Inter-American Affairs, with the task of encouraging and supporting the study of Latin America and of Spanish and Portuguese in U.S. schools and colleges. Over the years at The American University, he chaired the Department of History and Government, directed the language center, served as Dean of the College of Arts and Sciences, and held a joint appointment in the Department of History and the School of International Service. He founded the prestigious Washington Semester Program, designed for undergraduates from around the United States to study politics in the nation's capital. Throughout his academic career he travelled extensively throughout Latin America; he spent sabbaticals in Mexico and Chile, and in India, where he helped establish a Latin American studies program at the School of Ifternational Studies in New Delhi. He continued to teach part time at The American University after his retirement.

Harold was a prolific writer-all the more remarkable given his demanding administrative posts (which he accepted reluctantly) and heavy teaching commitments (which were at the fore of his vocation). Among his twenty-six books, which indicate a broad range of interests and major contributions, he authored History of the Western Hemisphere (1935, 1938), Latin American Social Thought (3d ed., 1966), The Americas in History (1953), Makers of Democracy in Latin America (1945, reissued in 1966), Latin American Thought (1972); and edited and coauthored Government and Politics in Latin America (1958), Latin American Diplomatic History (1977), and Latin American Foreign Policies (1975). His bibliography of other published works - chapters in books by others, journal articles, contributions to encyclopedias, pamphlets, and reports-includes at least 193 entries, in addition to at least 264 book reviews. He was in demand as an extracurricular lecturer; hardly a week passed during his fifty-year active career that he did not address a civic organization or university group. Harold was also an accomplished poet and musician.

Those of us who were privileged to be his students, colleagues, and friends, whose lives he enriched in so many ways, remember him with gratitude, admiration, and affection. Harold's students and associates were universally devoted to him--and they were, I think, because he was devoted to us. But there was nothing sentimental about his teaching - he was critical of those in our profession who, he said, "made teaching too easy." Toward his students he was at once gentle and demanding. Gentleness characterized all of his relationships; even his advice was indirect, related to his own broad experience, sometimes phrased as a parableand always on the mark. The results of Harold's teaching, moral vision, friendship, and example are a tangible immortality - they live on, not only in our memories, but in our work and our values.

Harold Davis wrote his own epitaph: "He lived to teach and hoped to leave behind a loving flame of learning in some mind." 